\title{
建物被害データと再現強震動による $\mathrm{RC}$ 造建物群の被害予測モデル DAMAGE EVALUATION MODELS OF REINFORCED CONCRETE BUILDINGS BASED ON THE BUILDING DAMAGE STATISTICS AND SIMULATED STRONG MOTIONS
}

\author{
長戸 健一郎*，川 瀬 博** \\ Kenichiro NAGATO and Hiroshi KAWASE
}

\begin{abstract}
In this paper, we try to estimate the actual yield strengths of reinforced concrete (RC) buildings based on the damage statistics in Kobe surveyed after the Hyogo-ken Nanbu earthquake of 1995 and nonlinear response analyses for synthetic waveforms simulated by Matsushima et al. (2000). First, we construct a set of building models that represents the RC building stock in Kobe and we create a plausible nonlinear multi-degrees-of-freedom models for four different heights of buildings based on the current code and practice. We must assume the damage criterion and the strength distribution a priori. When we calculate the damage ratios for these standard models we find that they are so high that we must increase the average yield strengths in order to match the calculated damage ratios to the observed. The estimated average yield strengths are much higher than those based on the code, especially for low-rise buildings. Using this set of building models we succeed to reproduce the belt-shaped area with high damage ratios in Kobe.
\end{abstract}

Keywords : damage evaluation, reinforced concrete building, building damage ratio, simulated strong motion 被害予測、RC 造建物、建物被害率、再現強震動

\section{1. はじめに}

地震時に建物群が受ける被害を定量的に推定することは、都市の 地震防災を考える上で極めて重要なことである。そのためには、建 物の耐震性能を正しく評価する必要がある。また同時に、入力とな る地震動も適切に推定されるべきである。これらの研究は、1995 年 兵庫県南部地震以降、特に注目され、様々な成果が発表されている。 しかしその多くは個別建物の評価を目的としたもので、面的あるい は統計的評価を目的とした研究は比較的少ない。これは主として実 際に建物に入力したであろう強震動を面的に評価することが困難で あったためと考えられる。

こうした面的あるいは統計的なアプローチを試みたものとして宮 腰ら ${ }^{1,2)}$ の研究が挙げられる。彼らはまず兵庫県南部地震における神 戸市及びその周辺地域の面的な最大地動速度分布を低層住宅の被害 率から推定し、その分布と建物の被害調查をもとに用途・高さ別の 被害関数を構築した。さらに、入力地震動レベルと建物構造特性と を関連づけた上で地震応答解析により被害関数を求め、建物被害テ 一タから求めた被害関数との関係について比較・考察を行った。ま た、林ら ${ }^{3}$ は兵庫県南部地震において比較的被害の多かった 6 階建 て以上の建物を含む RC 造建物被害調查結果とやはり低層住宅の被 害率から推定した最大地動速度分布の推定結果を基に、 RC 造建物の
被害と地震動強さの関保、さらに被害建物の耐震性能についてマク ロな観点から分析・検討を行っている。これらの先駆的研究は有用 な結果を提供してくれているが、構造物モデルとしては一自由度系 に置換されており、層間変形の高さ方向分布など多層構造物の応答 はモデル化されていない。また指標とされている面的な入力地震動 レベルは建物被害率から推定したものなので、それから再び建物被 害率を推定するということは、構造物のタイプが違うとはいえ、循 環論法に宿る危険性をはらんでいる。

被害地域での面的な入力を定量的に評価することは観測記録のみ では不可能である。しかし、最近の強震動地震学の進展と被災地で の地下構造探查によって神戸地域での強震動波形を精度よく再現す ることが可能となってきている。すなわち、松島ら ${ }^{4} に$ 見られるよ うに、震源と地下構造の不均質性を考慮することにより数値シミュ レーションで広い領域において観測記録を良く再現するとともに 「震災の帯」に良く対応する大速度振幅城を生成することができる ようになった。

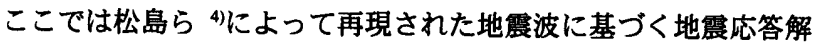
析之兵庫県南部地震の RC 造建物被害データを用いて、既存 RC 造建 築物群の耐力を推定し、観測被害データを良く再現できる耐力分布 を有する被害予測モデルを策定する。以下、まずはじめに本論で用

* 九州大学大学院人間環境学府 大学院生 ·修士 (工学)

** 九州大学大学院人間環境学研究院 教授. 工博

Graduate School of Human-Environment Studies, Kyushu University, M. Eng. Prof., Faculty of Human-Environment Studies, Kyushu University, Dr. Eng. 
いた耐力の推定手法について記述し、次に本論で用いる建物被害調 查データとそれに基づき算定した被害率（以後、観測被害率と呼ぶ） について示す。さらに地震底答解析に用いる建物モデルと入力地震 動について述べた後、これらに基づいた建物耐力の推定結果を示し 考察を加える。最後に推定した耐力を用いて解析領域の被害分布を 算定し、実被害との比較・検討を行う。本論文で提案する被害予測 モテルにより、予測強震動が与えられれば RC 造構造物の被害が予 測できるようになるとともに、今後の耐力の增大や低下が与える影 響なども評価可能となる。また、このモテルに観測地震動を入力す ることにより、地震動の建物破壊能力を評価、比較することも可能 となる。

\section{2. 耐力の推定手法}

著者らは以下に示す手順で既存 RC 造建物の耐力を推定した。

1)兵庫県南部地震の $\mathrm{RC}$ 造建物の被害調查結果 ${ }^{5)}$ に基づき、観測被害 率を求める。

2)設計基準に基づき建物モデルを設定する。本論では、これを標準 建物モデルと定義し、耐力推定の基準とする。

3)標準建物モテルの地震応答解析を行い、設定した破壊クライテリ アに基づきモデルの被害の有無を決定し、被害率を求める（以後、 解析被害率と呼ぶ）。

4)観測被害率と解析被害率を比較し、有意な差があれば、モデルの 耐力を変更し、再度地震応答解析を行い新たな解析被害率を得る。 5)解析被害率が観測被害率をほぼ再現できるまで 4)の手順を繰り返 す。

\section{3. 锶測被害率の算定}

日本建築学会近畿支部により、兵庫県南部地震における RC 系建 築物の全数調査 ${ }^{5}$ が行われている。調査は神戸市灘区・東灘区での 震度階 7 の区域内に建つ RC 系建築物全 3911 棟（うち 3534 棟は一 般建物、残り 377 棟はピロティ形式建物）について行われており、 階数別、建設年代別のデータとなっている。本論では、建物群の面 的な耐震性能を把握することに焦点をあてているので、少数ながら その特性は一般構造物とは異なると考えられるピロティ形式建物は 除外する。そこで、一般建物データを用い、この調查で大破及び倒 壊と判定された棟数を被害棟数とし、それを全棟数で割ったものを 観測被害率と定義する。ここで、1 階建て及び 14 階建て以上の建物 は被害棟数がほとんどなく、総数も少ないので除外し、2 階建てか ら 13 階建ての建物データを用いることにする。また、建設年代区分、 建物階数等が不明なデータも除き、最終的に Table1 に示す 3341 棟 のデータを用いる。さらに、1981 年の改正建築基準法施行をふまえ て、データを建設年代で 1982 年以前（以後、旧耐震と呼ぶ）と 1982 年以降（以後、新耐震と呼ぶ）の 2 つに分けてそれぞれの被害率を 算定することにする。また、建物高さの違いによる周期特性の違い を考慮し、3,6,9,12 階建てを想定した 4 種類のモデルに合わせて観測 被害率を算定する。具体的には $\mathrm{n}$ 階建てのモテルは $\mathrm{n}$ 階建ての建物 に加え $(\mathrm{n} \pm 1)$ 階建ての建物被害率を代表するものと考える。Table 1 と Fig.1 に算定した観測被害率を示す。従来から言われているように 中層（6-9 階建て）の被害率が比較的高く、また、新旧耐震で有意な 差があることがわかる。なお、12 階建モデルに関しては、新耐震の
方が旧耐震より被害率が大きくなっているが、これは、被害棟数、 全棟数ともにデータが少ないためと考えられる。Fig.2 に各モデルの 存在比率を示したが、3,6F モデルで全体の 9 割以上を占めているこ とがわかる。

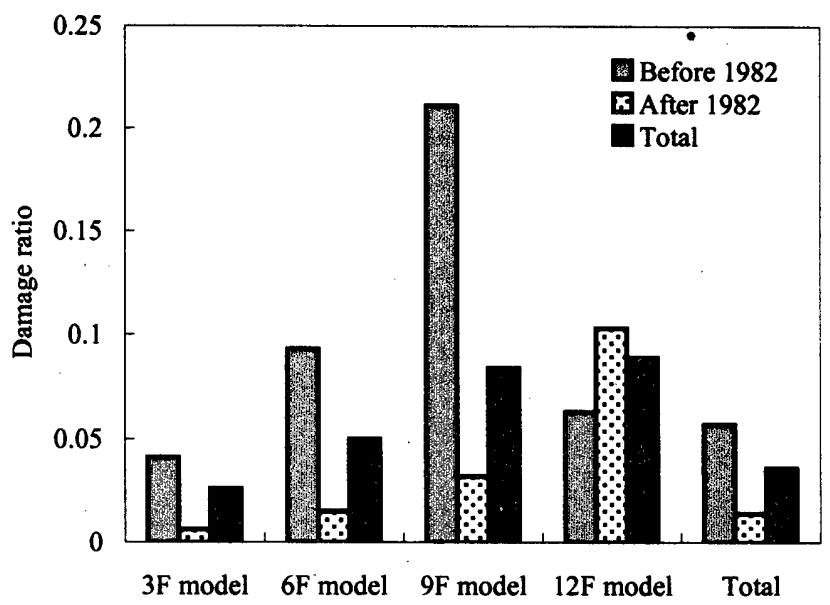

Figure 1. Observed damage ratios based on building damage data listed in Table 1 , which are separately calculated for floor numbers $(3,6,9$, and 12$)$ and construction age (before 1982 and after 1982) .

Table 1. Building damage data based on the survey in Kobe conducted by Architectural Institute of Japan Kinki Chapter.

\begin{tabular}{|c|c|c|c|c|c|c|c|c|}
\hline & Storv no. & $2 \mathrm{~F}$ & $3 \mathrm{E}$ & $4 \mathrm{~F}$ & $5 \mathrm{~F}$ & $6 \mathrm{E}$ & $7 \mathrm{~F}$ & \\
\hline \multirow{4}{*}{$\begin{array}{c}\text { Before } \\
1982\end{array}$} & Severe & 4 & 8 & 15 & 8 & 1 & 6 & \\
\hline & Collanse & 3 & 6 & 16 & 17 & 3 & 3 & \\
\hline & $\begin{array}{l}\text { Number of } \\
\text { buildings }\end{array}$ & 217 & 515 & 536 & 293 & 60 & 55 & \\
\hline & Damage ratio & \multicolumn{3}{|c|}{2.041} & \multicolumn{3}{|c|}{0.093} & \\
\hline \multirow{4}{*}{$\begin{array}{l}\text { After } \\
1982\end{array}$} & Severe & 0 & 1 & 2 & 3 & 2 & 3 & \\
\hline & Collaose & 0 & $\perp$ & 3 & 0 & 0 & 1 & \\
\hline & $\begin{array}{l}\text { Number of } \\
\text { buildings }\end{array}$ & 82 & 427 & 459 & 309 & 120 & 92 & \\
\hline & Damage ratio & \multicolumn{3}{|c|}{0.006} & \multicolumn{3}{|c|}{0.015} & \\
\hline \multirow{2}{*}{ Total } & No. of damage & 1 & 16 & 36 & 28 & 6 & 13 & \\
\hline & No. of buildings & 299 & 942 & 995 & 602 & 180 & 147 & \\
\hline & Story ne. & $8 \mathrm{E}$ & gF & $10 \mathrm{~F}$ & $11 \mathrm{E}$ & $12 \mathrm{E}$ & $13 E$ & Total \\
\hline \multirow{4}{*}{$\begin{array}{c}\text { Before } \\
1982\end{array}$} & Severe & 1 & 1 & 1 & 1 & 0 & 0 & 46 \\
\hline & Collaose & 3 & 1 & 1 & 0 & 0 & 0 & 53 \\
\hline & $\begin{array}{l}\text { Number of } \\
\text { buildings }\end{array}$ & 23 & 7 & 8 & 15 & 0 & 1 & 1730 \\
\hline & Damage ratio & \multicolumn{3}{|c|}{0.211} & \multicolumn{3}{|c|}{0.063} & 0.057 \\
\hline \multirow{4}{*}{$\begin{array}{l}\text { After } \\
1982\end{array}$} & Severe & 0 & 2 & 1 & 2 & 0 & 1 & 17 \\
\hline & Collanse & 0 & 0 & 0 & 0 & 0 & $e$ & 5 \\
\hline & $\begin{array}{l}\text { Number of } \\
\text { buildings }\end{array}$ & 45 & 25 & 23 & 19 & 9 & 1 & 1611 \\
\hline & Damage ratio & \multicolumn{3}{|c|}{0.032} & \multicolumn{3}{|c|}{0.103} & 0.014 \\
\hline \multirow[b]{2}{*}{ Total } & No. of damare & 4 & 4 & 3 & 3 & 0 & 1 & 121 \\
\hline & No. of buildings & 68 & 32 & 31 & 34 & 9 & 2 & 3341 \\
\hline
\end{tabular}




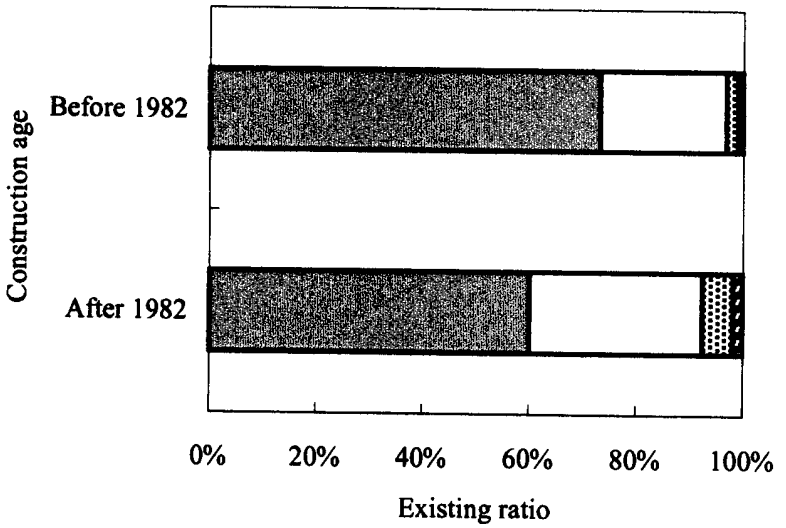

궁 $3 \mathrm{~F}$ model $\square 6 \mathrm{~F}$ model $49 \mathrm{~F}$ model $12 \mathrm{~F}$ model

Figure 2. Existing ratios of building models calculated from building data shown in Table 1, separately for construction age (before 1982 and after 1982).

\section{4. 地震応答解析}

\section{1 建物モテル}

3 章で述べたように解析には 3,6,9,12 階建てを想定したの 4 種類の モデルを用いる。モデルは多質点せん断型モテルで、各層の復元力 特性は Degrading tri-linear 型（以後、D-tri 型）とし、減衰は瞬間剛性 比例型、減衰定数は $5 \%$ とする。また、解析には Newmark の $\beta$ 法を 用い、 $\beta=1 / 4(0.25)$ 、時間間隔は $0.005 \mathrm{~s}$ とする。

モデルの各層の耐力は次式で定義する。

$$
\mathrm{C}_{\mathrm{yi}}=\mathrm{A}_{\mathrm{i}} \mathrm{C}_{\mathrm{y}}
$$

ここで、 $\mathrm{C}_{\mathrm{yi}}$ は $\mathrm{i}$ 層の層せん断力係数、 $\mathrm{A}_{\mathrm{i}}$ は高さ方向の分布を示す俰 数 ( $\mathrm{A}_{\mathrm{i}}$ 分布)、 $\mathrm{C}_{\mathrm{y}}$ は降伏ベースシア係数である。各モデルの $\mathrm{A}_{\mathrm{i}}$ 分布 形状を Fig.3 に示す。なお、旧耐震の建物は $\mathrm{A}_{\mathrm{i}}$ 分布で耐力が規定さ れていたわけではなく、規定上は旧耐震の水平震度分布がこれに替 わるものと考えられるが、実際には各階ともほぼ同一の柱断面を用 いるなど計画上の理由から上層の酎力に余裕をもたせた設計が多い ものと推定される。実際の建物の耐力分布に関する確かな情報は得 られていないので、ここではこうした現実的な設計プラクティスを 考虑し同じ $\mathrm{A}_{\mathrm{i}}$ 分布を仮定した。

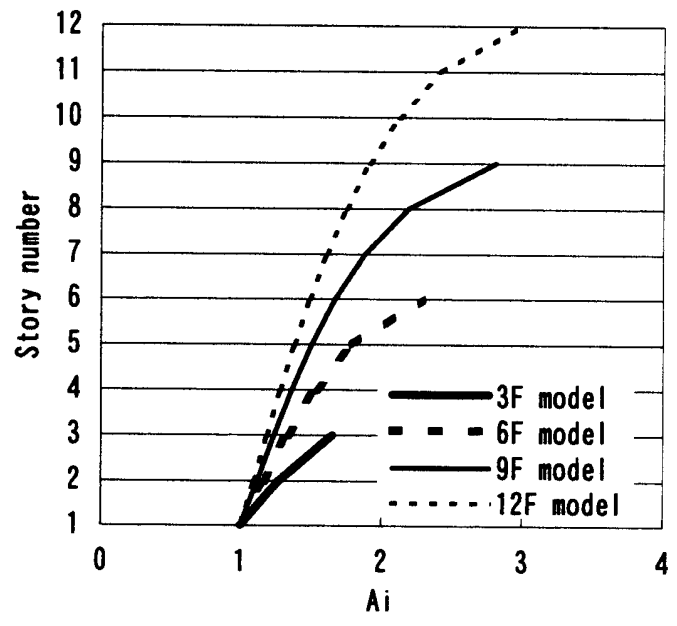

Figure 3. $A_{i}$ distributions separately for $3,6,9$, and 12 model.

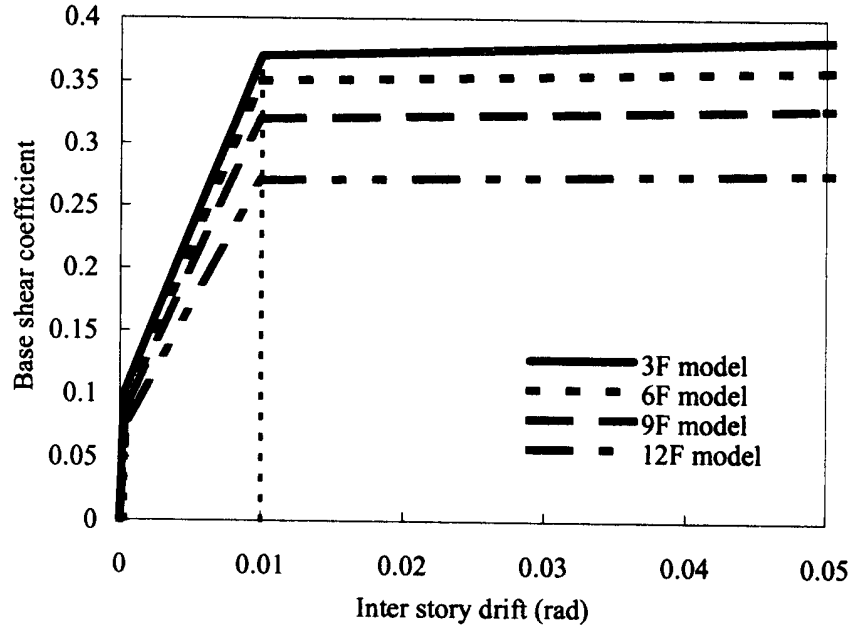

Figure 4. Nonlinear relationships at the basement of standard models

Table 2. Parameters of standard building models

\begin{tabular}{|c|c|c|c|c|c|}
\hline & & 35 model & $6 \mathrm{~F}$ model & $9 \mathrm{E}$ model & $12 \mathrm{E}$ model \\
\hline \multirow{12}{*}{$\begin{array}{l}\text { Weight } \\
\text { (tf) }\end{array}$} & 1 & 139 & 397 & 397 & 397 \\
\hline & 2 & 131 & 368 & 368 & 368 \\
\hline & 3 & 131 & 360 & 360 & 360 \\
\hline & 4 & & 343 & 343 & 343 \\
\hline & 5 & & 339 & 339 & 339 \\
\hline & 6 & & 336 & 336 & 336 \\
\hline & 7 & & & 332 & 332 \\
\hline & 8 & & & 328 & 328 \\
\hline & 9 & & & 318 & 318 \\
\hline & 10 & & & & 318 \\
\hline & 11 & & & & 317 \\
\hline & 12 & & & & 413 \\
\hline \multirow{12}{*}{$\begin{array}{l}\text { Story height } \\
\text { (cm) }\end{array}$} & 1 & 383 & 465 & 465 & 465 \\
\hline & 2 & 358 & 370 & 370 & 370 \\
\hline & 3 & 355 & 360 & 360 & 360 \\
\hline & 4 & & 355 & 355 & 355 \\
\hline & 5 & & 350 & 350 & 350 \\
\hline & 6 & & 350 & 350 & 350 \\
\hline & 7 & & & 350 & 350 \\
\hline & 8 & & & 350 & 350 \\
\hline & 9 & & & 350 & 350 \\
\hline & 10 & & & & 350 \\
\hline & 11 & & & & 350 \\
\hline & 12 & & & & 350 \\
\hline \multicolumn{2}{|c|}{$\begin{array}{c}1^{x} \text { yield } \\
\text { inter story drift }(\mathrm{rad}) \\
\end{array}$} & 0.0003 & 0.0004 & 0.0004 & 0.0005 \\
\hline \multicolumn{2}{|c|}{$1^{\text {a }}$ yield base shear coef. } & 0.1 & 0.09 & 0.09 & 0.08 \\
\hline \multicolumn{2}{|c|}{$\begin{array}{l}2^{\text {nd }} \text { yield } \\
\text { inter story drift (rad) }\end{array}$} & 0.01 & 0.01 & 0.01 & 0.01 \\
\hline \multicolumn{2}{|c|}{$2^{\text {nd }}$ yield base shear coef. } & 0.37 & 0.35 & 0.32 & 0.27 \\
\hline \multicolumn{2}{|c|}{$1^{\text {"n natural period }}$} & 0.30 & 0.49 & 0.57 & 0.77 \\
\hline \multicolumn{2}{|c|}{$2^{\text {sd }}$ natural period } & 0.13 & 0.20 & 0.23 & 0.30 \\
\hline
\end{tabular}


モデルの設定にあたっては、文献 のに低層 RC 造（3 階建て）建物、 中層 RC 造（12 階建て）建物の設計例が示してあり、本論ではそれ を参考にする。3 階建て建物に関しては現行の新耐震基準に、12 階 建て建物に関しては 1990 年制定の日本建築学会編「鉄筋コンクリー 卜造建物の終局強度型耐震設計指針」に基づいて設計されている。 そこで、本論ではこれらの例に示されている建物を、現在の標準的 な設計耐力を持った標準建物モデルとみなし、その耐力を標準設計 耐力として定義し、既存 RC 建物群の耐力推定の基準とした。6 層モ テルと 9 畠モデルに関しては適当な例がないため、 3 層と 12 層の中 間の耐力を持つとして耐力を設定した。なお、本論では、D-tri 型の 第 2 降伏点に対応するべースシア保数を建物耐力と考えることにす る。標準建物モデルの緒元を Table2 に、復元力特性を Fig.4 に示す。

\section{2 入力地霞動}

松島ら ${ }^{4)}$ は六甲山地から大阪湾までの、震災の帯を含む $42 \mathrm{~km} \times$ $18 \mathrm{~km}$ の領域で 3 次元有限差分法を用いた強震動シミュレーションを 行っている。そこで、本論ではその再現波を入力地震動として用い た。再現波形は $80 \mathrm{~m}$ メッシュで、 $42 \mathrm{~km} \times 18 \mathrm{~km}$ の領域すべての点で 得られているが、本論では、 $\mathrm{x}$ 軸方向 $\left(\mathrm{N} 57^{\circ} \mathrm{E}\right) 160 \mathrm{~m} 、 \mathrm{y}$ 軸方向 $\left(\mathrm{S} 33^{\circ}\right.$ E ) $80 \mathrm{~m}$ ピッチで、Fig.5 に示す建物被害データの得られている嚾・ 東灘区（中央区・芦屋市の一部を含む）の領域を網羅するメッシュ

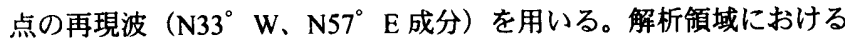
再現波の最大速度分布を Fig.6に示す。いわゆる震災の帯と呼ばれる 領域で大きな速度が見られ、観測事実と対応していることがわかる。 なお、本論文では大阪層群上面の再現波をそのまま基䃈固定の構造

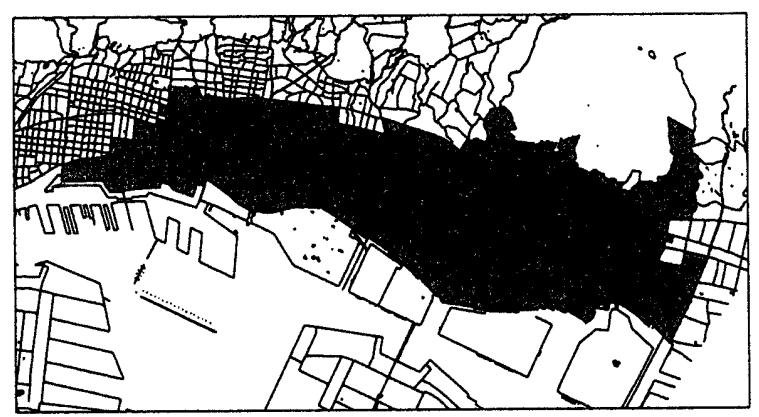

Figure 5. Analyzed area using in this study.

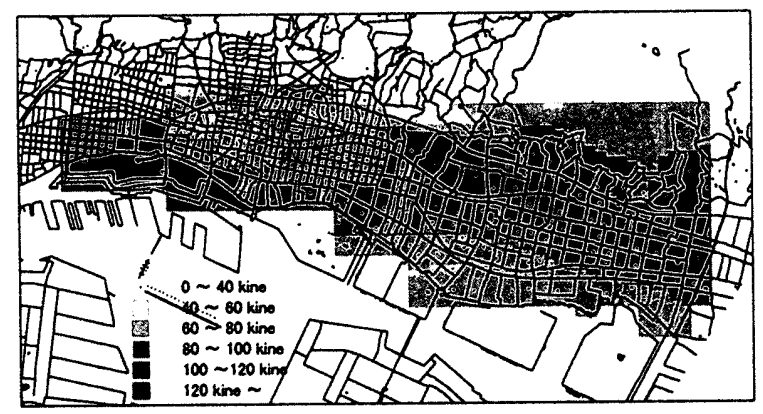

Figure 6. Peak ground velocity distribution of strong motions used for the estimation of the building strengths.
物に入力しており、表層地盤の増幅を考慮していない。これは再現

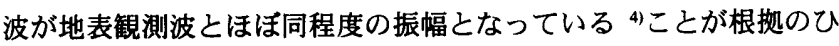
とつであるが、地盤の非線形化や相互作用効果によりこの増幅効果 がかなり相殺されるということも考虑して判断したものである。し かし、その影響の定量的評価については今後検討していきたい。

\section{5. 既存 $R C$ 造建物の耐力推定}

\section{1 標準建物モテルの解析被害率}

解析被害率の算定にあたっては、次のような仮定を用いる。

1) 建物群の耐力 $\mathrm{C}_{\mathrm{y}}$ にばらつきを与え、同一レベルの地震動でも、被 害の有無が生じるとする。

2)建物耐力の確率密度分布として Shibata ${ }^{7}$ が 1978 年宮城県沖地震の 被害調查（1 層〜 5 層建築物で、 3 層建築物が約半数）に基づき求 めた平均値 0.095 （実值として 1.1）、標準偏差 0.423 の対数正規分 布を採用し、この分布にベースシア係数をかけたものを耐力分布 として用いる。

3)モテルの破壊クライテリアとして、RC 柱の実験結果 ${ }^{81.9)}$ によれば 層間変形角 $1 / 50$ 程度で最大耐力を発揮し、その後 $1 / 25$ 程度まで 徐々に耐力が低下するとされているので、本論では、最大層間変 形角が 1/30 rad 以上になったモデルが大破以上の被害を受けたも のとする。

4)被害を受けたモデルの存在比率を合計したものを被害率と考える。 5) $\mathrm{N} 33^{\circ} \mathrm{W}$ 成分・ $\mathrm{N} 57^{\circ} \mathrm{E}$ 成分どちらかの結果が仮定 3)を満たせば、 被害を受けたとし、4)の仮定により解析被害率を求める。

6)建物データに基づき市販 GIS のソフトウェアである SIS を用いて 建物存在比率を求め、それを重み関数として、各再現波毎に得ら れた解析被害率を合計したものをそのモテルの解析被害率とする。 なお 3)の破壊クライテリアは建設年代によらないとしているが、こ れは新旧耐裖の推定耐力を定量的に比較するためである。1982 年以 前の建物群においては、RC 骨組の実駼結果 ${ }^{10), 11)}$ より最大荷重時の層 間変形角は $1 / 70 \sim 1 / 60$ となっており、その平均耐力は 1982 年以降の 建物に比べ相対的に過小評価されることになる。

以上のような仮定を用いて標淮耐力を持つ建物群の解析被害率を 算定する。ここで仮定 2)について少し説明を加えておく。Fig.7には Shibata $^{7}$ の確率密度分布を示す。この分布から 11 ケースの建物耐力 を代表值とし、その存在比率を求め解析に用いる。Fig.8にその代表 値と存在比率の関係を示す。すなわち、建物群の耐力は、この代表 值にベースシア倸数に掛けたものとなる。Fig.8の代表值の数が多い ほど解析の精度は高くなるが計算時間は増大する。この代表値の数 を変えて $(9,11,15$ の 3 パターン) 被害率を比較したが、特に目立つ た差は見られなかった。しかし、代表值が 9 ケースである場合は存 在比率の組み合わせが少ないため表現できる被害率が限られ被害分 布がスムーズに表現されないので、本解析では代表値の数として 11 ケースを採用した。なお、この耐力分布は建物高さの関数と考えら れるが、現在のところ中高層構造物の耐力分布に関する情報がほと んどないので、ここでは階数に関わらず同じ分布を仮定した。この 分布の形状自体は本論文の主眼としている平均耐力の推定にはそれ ほど影響しないことを別途確認している。算定結果を Fig.9 に示す。 比較のため、Fig.1 に示した観測被害率も同時に示す。Fig.9より明ら かに、解析被害率の方が高く、既存 RC 建物群は標準設計耐力より 
も大きな耐力をもっていなければ、観測事実を再現できないことが わかる。

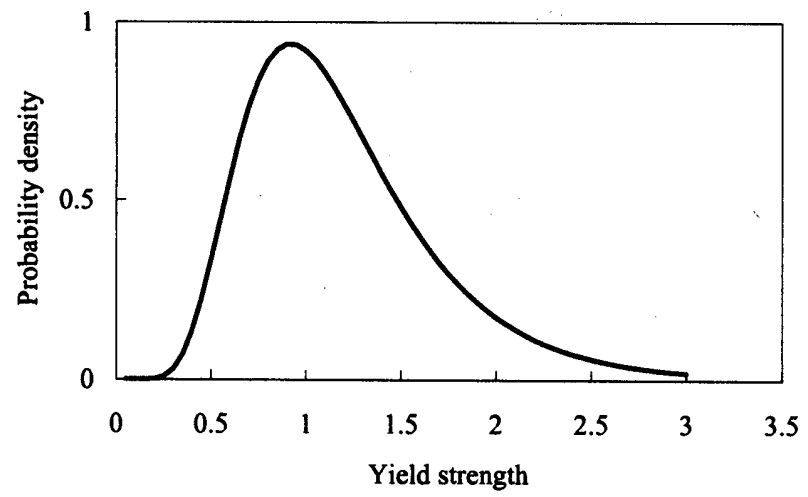

Figure 7. Probability density distribution of yield strength predicted by Shibata ${ }^{7)}$

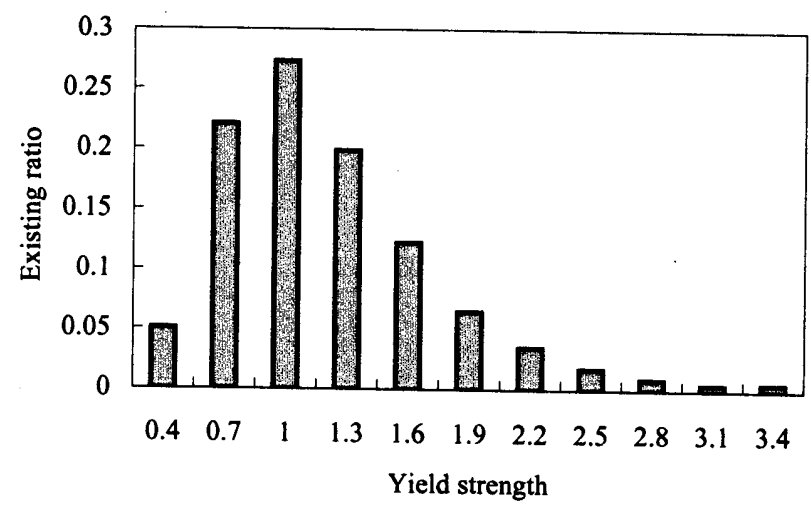

Figure 8. Relationships between yield strength and its existing ratio based on probability density distribution shown in Fig. 7.

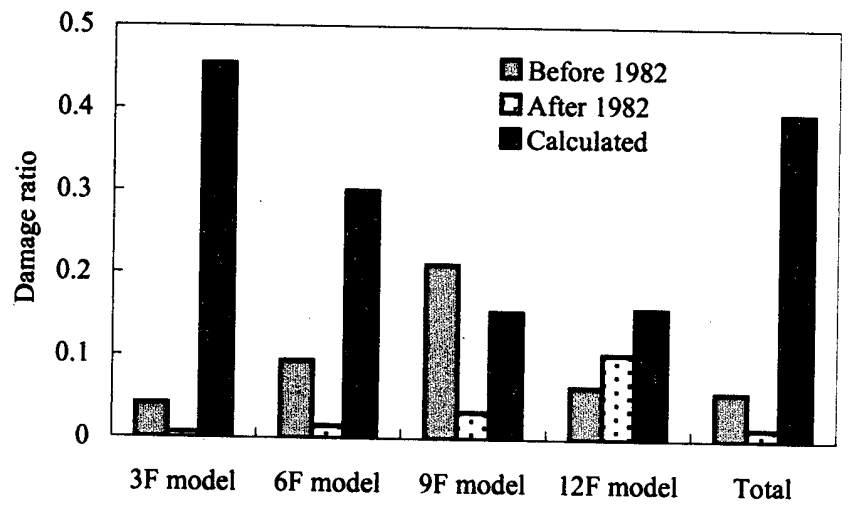

Figure 9. Calculated damage ratios of standard building models, which are compared with observed damage ratios.

\section{2 耐力の推定}

建物群の耐力推定にあたり、標準建物耐力との比を $\alpha$ と定義する $\alpha$ を標準建物モデルのベースシア俰数に掛け、その耐力を用い、観 測被害率に漸近するまで解析を繰り返した。なお、 $\alpha$ は 0.05 刻みで 変化させた。その結果、Fig.10に示す $\alpha$ の值において、Fig.11 に示す ように各モデルの解析被害率が観測被害率に良くフィットした。な お、図中 Total の解析被害率は Fig.2 の各モデルの存在比率を重み関
数として、各モデルの被害率を合計したものである。当然のことな がらこれも良くフィットしている。ここで推定された $\alpha$ は旧耐震の9 階建モテルを除き 1.0 よりも大きく、既存 RC 造建物は設計基準で考 慮されているよりも大きな耐力を持つものと推定される。また、低 層モテルほど $\alpha$ の値は大きく、より高い実保有耐力を有しているこ とが推察される。これは、低層建物ほど耐力算定には考慮されてい ない非構造壁の寄与が大きいものと考えられる。また、推定された 耐力を持つモデル゙ Fig.8 に示す代表值が 1.0 のケース、すなわち仮 定において一番大きな存在比率を有するモテルについて、推定に用 いた波形のうち最大速度を持つ波を入力したときの各層の層間変形 角分布を Fig.12 に、各モテルの最大層間変形角を示した層の層間変 形角の時刻歴応答を Fig.13 に示す。Fig.12(a)は旧耐震のテータから 推定された建物モデルについて示しているが、6層、9 層モテルで第 1 層あるいは第 2 層で層崩壊が起きていることがわかる。観測事実 も震災の帯の中では中層建物の低層部崩壊がみられたので対応して いると思われる。Fig.12(b)は新耐震に対応するが、どのモテルにお いても破壊クライテリアである 1/30 rad を下回っており、新耐震の建 物には相対的に被害が少なかった観測事実に対応している。また、 Fig.13に示した時刻歴応答にも新旧耐震の挙動の違いが明睹に見ら れ、大破以上の被害とされたモデルでは最大変形角に近い残留変形 が残ることがわかる。また大破する場合は第 2 波で大破に至ること が示されている。

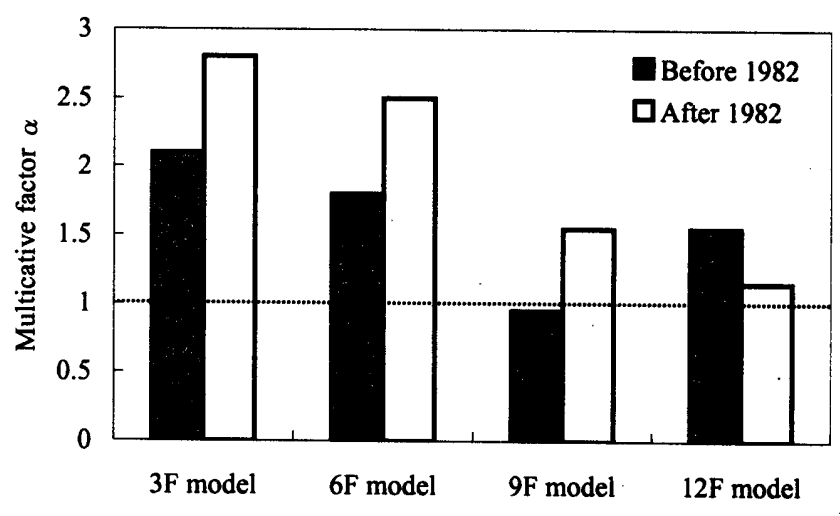

Figure 10. Estimated multiplicative factors, $\alpha$, separately for story numbers (3, 6, 9, and 12) and construction age (before 1982 and after 1982)

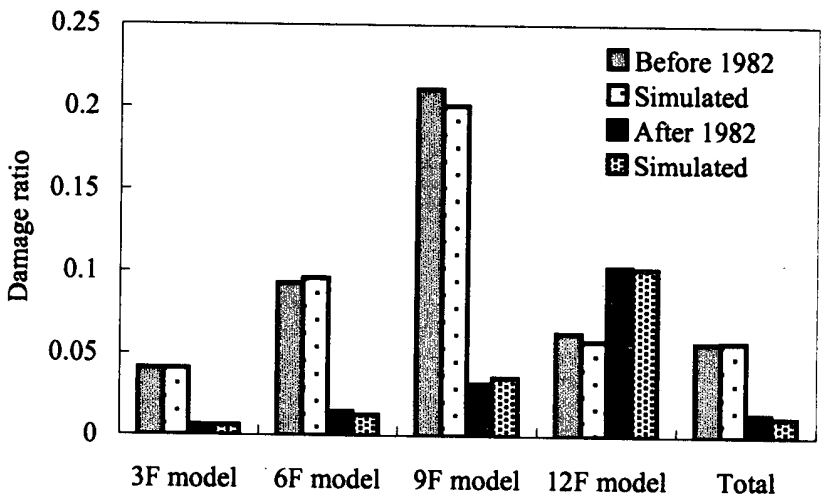

Figure 11. Simulated damage ratios of building models with their estimated strengths from multiplicative factors shown in Figure 9. 


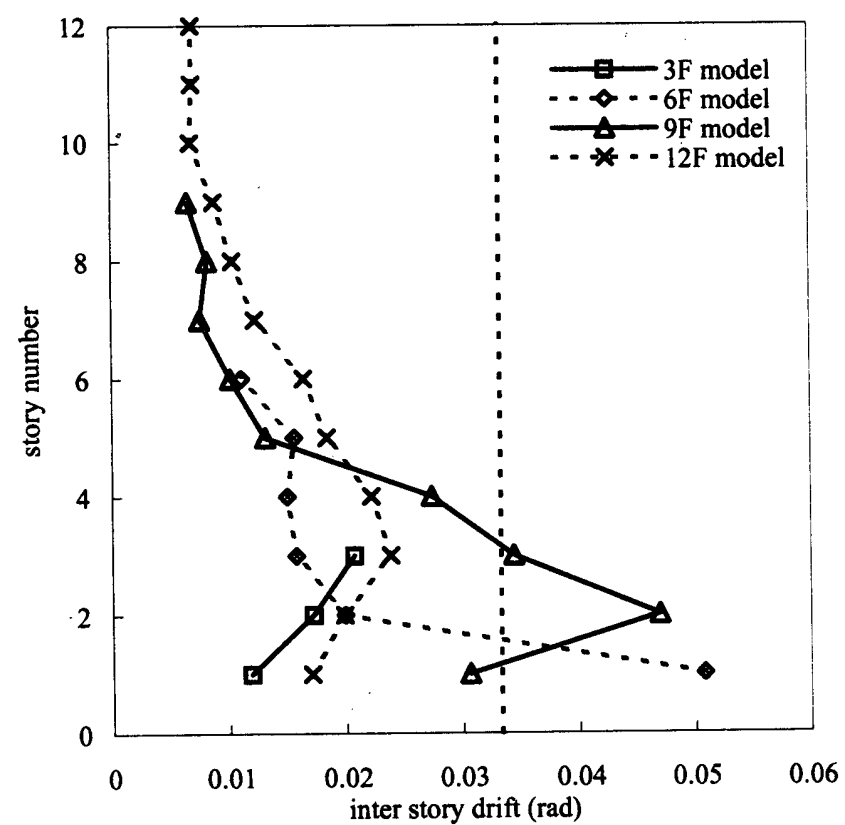

(a) Built before 1982

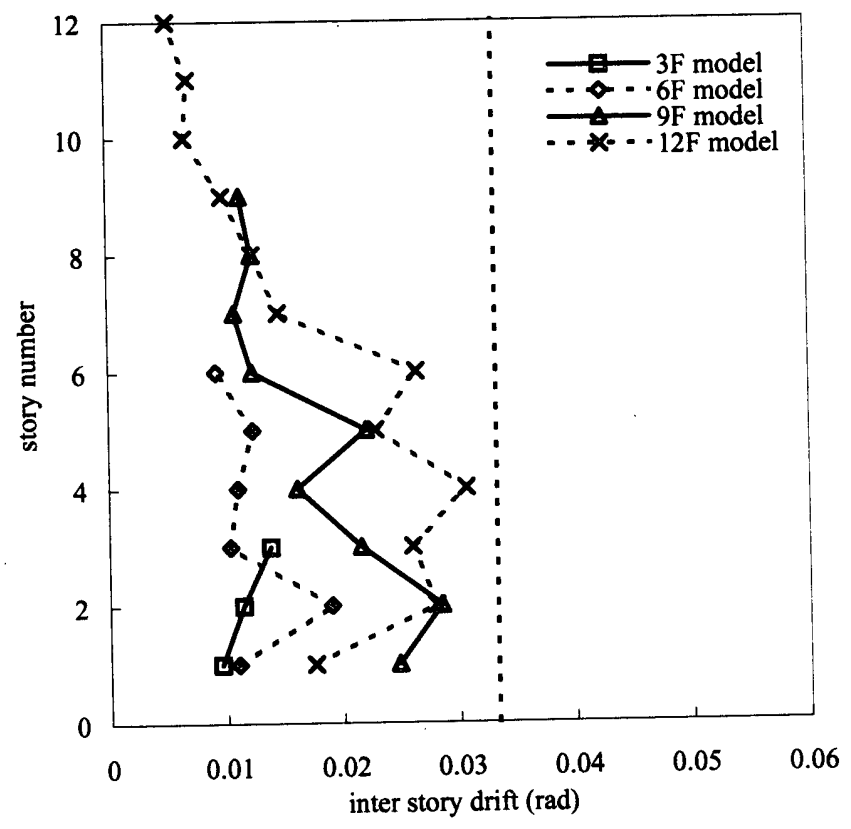

(b) Built after 1982

Figure 12. Maximum inter story drift distributions of building models which occupy the largest number of buildings.
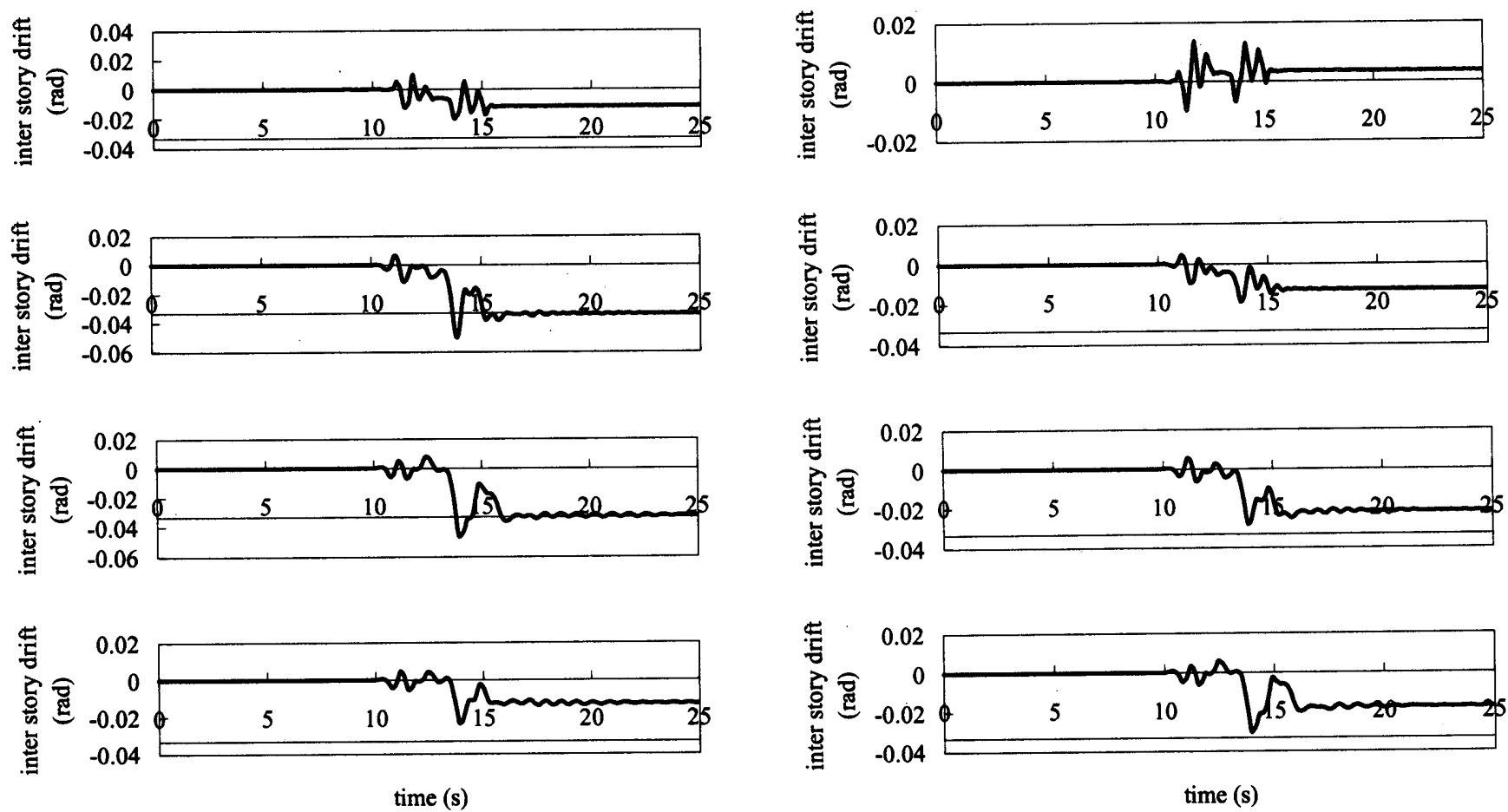

(a) Built before 1982

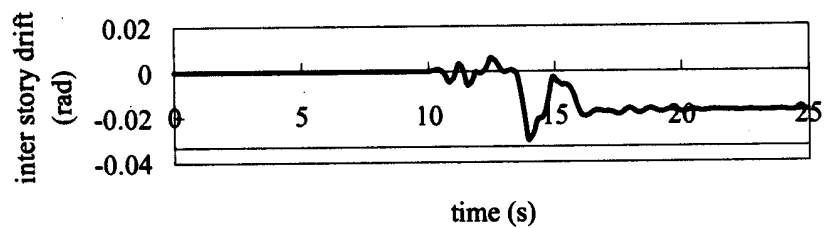

(b) Built after 1982.

Figure 13. Time histories of inter story drift of building models which occupy the largest number of buildings, shown from up side, for $3 \mathrm{~F}, 6 \mathrm{~F}$, $9 \mathrm{~F}$, and $12 \mathrm{~F}$ model, respectively.

\section{6. 解析被害率の平面的分布}

この章では、 5 章で推定された耐力による平面的な被害分布を示し、 推定耐力の妥当性を検証する。ここでは、SISにより、町丁目データ からメッシュに建物棟数データを与え、それに基づきメッシュ毎に各 モデルの存在比率を求めた。この比率をそのメッシュの再現波に基づ き求まった各モデルの被害率に掛け合計したものがそのメッシュの
被害率であるとした。被害率分布を建設年代別に Fig.14 に示す。ま た、同時に観測被害率分布も示した。Fig.14(a)は旧酎震として推定さ れた耐力を持つ建物群の解析被害率分布で、いわゆる震災の帯の形成 が見られる。観測被害率分布と比べても、解析被害率分布のほうが広 い範囲で被害がでているもの、全体的な傾向（被害がでている位置 等) はよく再現できている。Fig.14(b)は新耐震の推定耐力を持つ建物 
群の分布であり、同様の傾向が見られるが、その被害率は小さく、耐 震基準改正後の建物の被害率が低かったという観測事実と対応して いる。観測被害率分布との比較では、観測に比べかなり広い箸囲で被 害がでている。これは、Fig. 14(a)の比較においてもいえることだが、
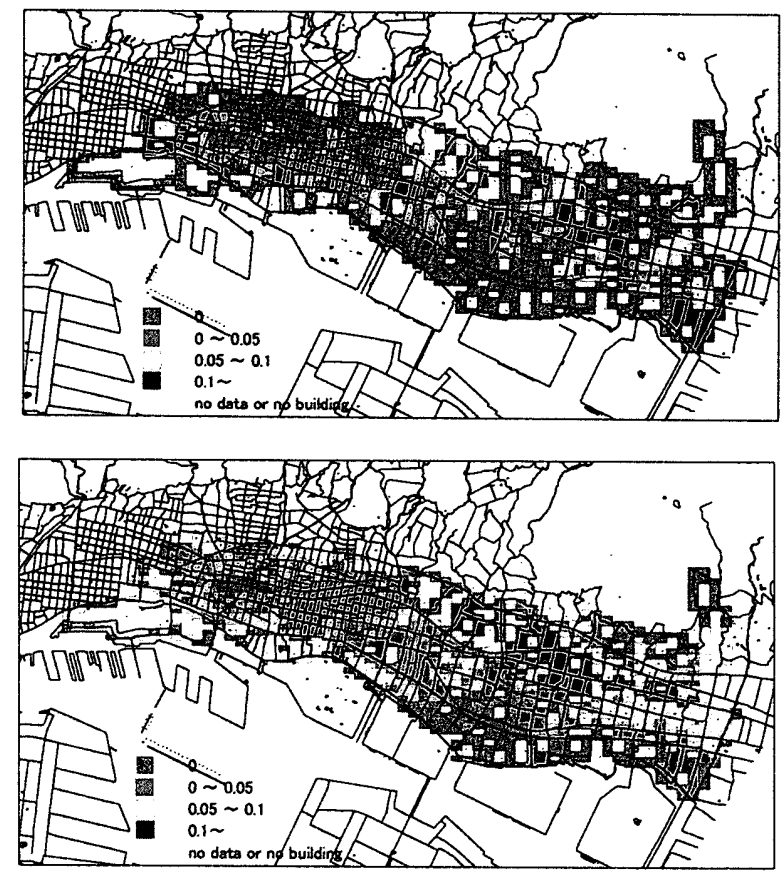

(a) Built before 1982
解析被害率は全領域の合計で評価しているため個々のメッシュの解 析被害率は観測被害率より低く評価されたことによると考えられる。 いいかえると、観測被害率分布には際だって被害率の大きなメッシュ が存在するということである。これには社会的な要因が考えられよう。
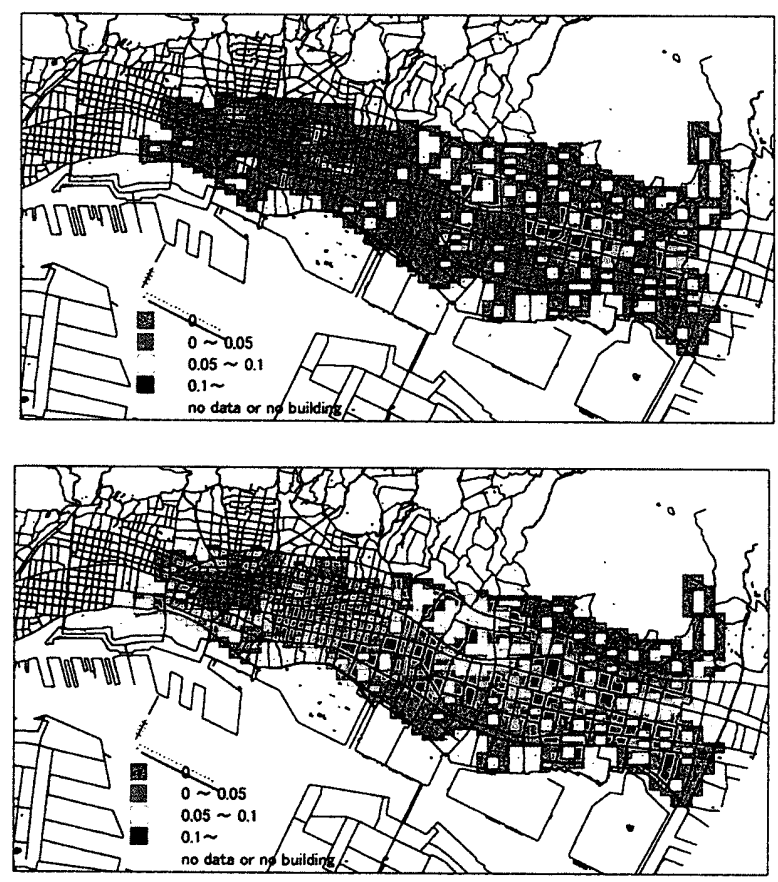

(b) Built after 1982

Figure 14. Damage ratio distributions, separately for construction age. upper, observed ; bottom, calculated

\section{7. まとめ}

兵庫県南部地震の建物被害データと再現波に基づく地震応答解析 の結果を用いて、既存 RC 造建物の耐力推定を行い、被害予測モテ ルを策定した。推定に際しては、建物高さの違いによる周期特性を 考慮して階層別に 4 種類のモテルを用いた。また、建築基淮法の改 正を考虑して、建設年代別に推定を行った。さらに、推定した耐力 を用いて被害率の平面的な分布を示した。以下に、解析結果から得 られた結論を述べる。

1)被害データから求めた被害率を良く再現できる建物耐力を推定す ることができた。

2)既存 RC 造建物は設計基準で考慮されているよりもずっと強い耐 力を保持しており、その傾向は低層建物ほど強い。この相違には 非構造壁の影響が大きいと考えられる。ただし、耐力分布が階数 依存の場合や破壊クライテリアが階数依存の場合など異なる仮定 をおけば異なる結果となると考えられるので、得られた耐力の絶 対值については今回の仮定下におけるものであると認識しておく 必要がある。

3)建物群の中で最も存在比率の高い耐力をもつモデについて層間 変形角分布、時刻歴層間変形角を示し、中層建物の低層部崩壊が 再現できていることを示した。

4)推定された耐力により得られた平面的な被害分布は、いわゆる震 災の帯といわれる領域で高い被害率が再現できている。観測被害 分布との比較でも、被害のでている範囲に多少の差はあるものの、 全体的な傾向はよく再現できている。

今後は、表層地盤の影響や地盤と建物の相互作用効果も取り入れ ていきたいと考えている。今回の解析で実構造物の耐力は標準的な モデルよりもずっと大きいことがわかった。しかし、その耐力比は モデル仮定に依存するもので、その検証が望まれる。

\section{铸辞}

日本建築学会近畿支部鉄筋コンクリート構造部会（主査、大阪大 学 大野義照教授）より貴重な建物被害データを提供していただき ました。紙面を借り、厚く御礼申し上げます。

参考文献

1)宮腰、林、渡辺、田村：1995 年兵庫県南部地震の建物被害に基づく建物の 耐震性評価、標造工学論文集、Vol.43B、pp.269-276、1997.3

2)宮鹿、林、田村 : 被害デー夕と地震応答解析に基づく建物群の耐震性能に関 する考察、第 10 回日本地鹿工学シンポジウム、pp.327-332、1998 3)林、宮腰、田才、大野: 1995 年兵庫県南部地震における $\mathrm{RC}$ 造建物群の耐霞 性能、日本建築学会構造系論文集、No.528、pp.135-142、2000.2

4)松島、川瀬：1995 年兵庫県南部地震の複数アスペリティモデルの提案とそ れによる強震䵢シミュレーション、日本建築学会構造系論文集、pp.33-40、 2000.8

5)日本建筑学会近幾支部鉄筋コンクリート侢造部会、1995 年兵庫県南部地震 コンクリート系建物被害調查報告書、1996

6)日本建筑学会、地祳荷重-地震動の予测と建築物の底答、1992

7)Shibata : Prediction of the probability of earthquake damage to reinforced concrete building groups in a city、 $7^{\text {th }}$ WCEE、Istanbul、Volume 4、pp.395-402、1980 8)廣灀、中澤、福山、國分、平石：せん断破壊後の和力低下防止を目的とした $\mathrm{RC}$ 柱の構造性能 その 1 実験概要と横補強筋比の比較、日本建築学会大 会学術講演梗概集（近畿）、pp.237-238、1996.9

9)中本、張、吉岡、森 : 高層 RC 構法「TOWERS-31」の開発その 4 柱部材実 験、日本建築学会大会学術講演梗概集（近幾）、pp.777-778、1996 10)江戸、武田、表：3 層 1 スパン铁筋コンクリート骨組の動的破烄実倹（そ の 1 実倹結果) 、日本建築学会大会学術講演梗概集（九州）、構造系、 pp.1119-1120、1972.10

11)坪䗁、中田、芳村、高橋：一日米共同研究一鉄筋コンクリート造実大 7 層試験体の酎震性に関する研究 その 13 試験体の保有水平耐力と変形性 状、日本建築学会大会学術講演梗概集、構造系、pp.1575-1576、1982 